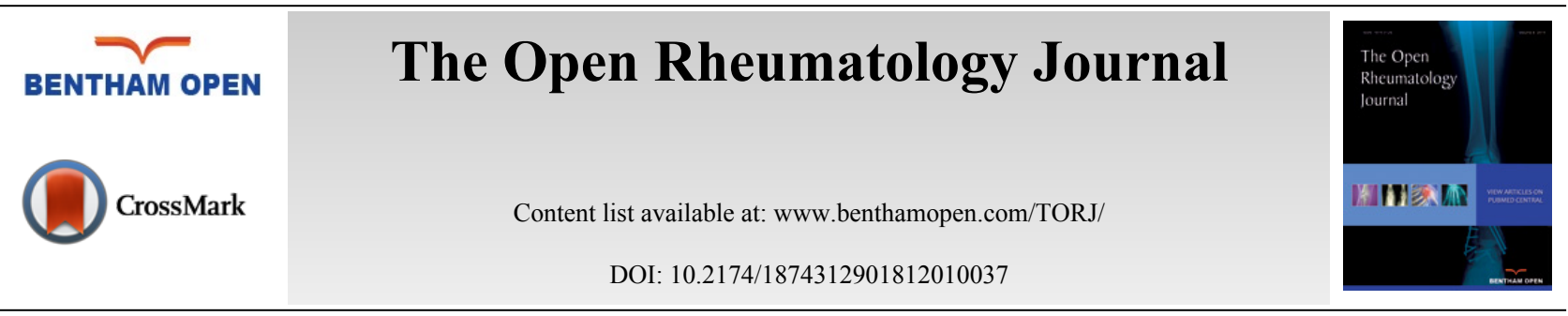

REVIEW ARTICLE

\title{
DNA Methylation in Osteoarthritis: Current Status and Therapeutic Implications
}

\author{
Antonio Miranda-Duarte* \\ Department of Genetics, Instituto Nacional de Rehabilitación "Luis Guillermo Ibarra Ibarra", Tlalpan, Mexico
}

Received: November 15, 2017

Revised: February 24, 2018

Accepted: March 5, 2018

\begin{abstract}
:
Background:

Primary Osteoarthritis (OA) is a multifactorial disease in which genetic factors are strongly associated with its development; however, recently it has been observed that epigenetic modifications are also involved in the pathogenesis of OA. DNA methylation is related to gene silencing, and several studies have investigated its role in the loci of different pathways or molecules associated to OA.
\end{abstract}

\section{Objective:}

This review is focused on the current status of DNA methylation studies related to OA pathogenesis.

\section{Method:}

A review of the literature was conducted on searching in PUBMED for original papers on DNA methylation in OA.

\section{Conclusion:}

The DNA methylation research of loci related to OA pathogenesis has shown a correlation between methylation and gene repression; however, there are some exceptions to this rule. Recently, the development of genome-wide methylation and genome-wide hydroxymethylation profiles has demonstrated that several genes previously associated with OA can have changes in their methylation status, favoring the development of the disease, and these have even shown the role of other epigenetic markers.

Keywords: Osteoarthritis, Epigenetics, DNA, Methylation, Cartilage, Chondrocyte.

\section{INTRODUCTION}

Osteoarthritis (OA) continues to be considered the most common joint disease and a leading cause of musculoskeletal disability worldwide. Its hallmark is the progressive degeneration of articular cartilage, resulting in joint space narrowing, osteophyte formation, and subchondral sclerosis that, taken together, are clinically translated as chronic joint pain, joint stiffness, limitation of movement, and a variable degree of inflammation [1]. OA is a complex disease in which genetics and environmental factors are strongly related to its development. Generally, it is classified as primary or idiopathic when no discernible cause is evident, and secondary when a triggering factor is apparent. Idiopathic OA, in particular, possesses a significant genetic component, and several genetic association studies have demonstrated its relationship with different genes, such as those involved with inflammation, Wnt signaling, Bone Morphogenetic Proteins (BMP), proteases, and Extracellular Matrix (ECM) proteins, among others [2]. However, there has not always been consistency in the results, probably due to different gene-gene and gene-environment interactions.

\footnotetext{
* Address correspondence to this author at the Department of Genetics, Instituto Nacional de Rehabilitación, Antonio Miranda-Duarte, Calzada México-Xochimilco 289, Col. Arenal Guadalupe, Deleg. Tlalpan, 14389 México City; Tel: (+52) (55) 59991000; E-mail: fovi01@prodigy.net.mx
} 
Epigenetics refers to heritable changes in gene expression that occur without changes in the DNA, and it comprises a mechanism through which gene-environment interactions could occur. Its mechanisms include DNA methylation, histone modifications, chromatin remodeling, and microRNAs (miRNA) [3]. Recent evidence has shown that epigenetic changes could affect the expression of genes involved in the pathogenesis of OA; this review is focused on the current state of DNA methylation studies related to OA pathogenesis.

\section{METHODS}

A PUBMED literature review was conducted searching for original papers on DNA methylation in OA, using the key words "osteoarthritis", "DNA methylation", "articular cartilage", and "chondrocyte".

\section{RESULT}

\subsection{Articular Cartilage and the Pathogenesis of Osteoarthritis}

A review of the pathogenesis of OA falls beyond the scope of this paper; however, the most important aspects are mentioned briefly. Articular cartilage is a highly specialized, avascular, and aneural connective tissue composed of ECM and chondrocytes. ECM is composed mainly of collagens and proteoglycans, among which type II collagen is the major constituent of ECM; this forms fibrils and fibers intertwined with proteoglycan aggregates. Other collagens, such as types I, IV, V, VI, IX, and XI, are present in a minor proportion. The second major component comprises the proteoglycan aggrecan; this interacts with hyaluronan to form aggregates and occupies the ECM interfibrillar space [4]. Chondrocytes are the unique cellular element of articular cartilage and, under physiological conditions, are responsible for a subtle balance between ECM synthesis and degradation. These cells are produced during chondrogenesis, which is the cartilage differentiation process that leads endochondral ossification to skeletal formation. The chondrogenesis process consists of the condensation of Mesenchymal Stem Cells (MSC), differentiation into chondrocytes, proliferation, and hypertrophic maturation. Proliferating chondrocytes are characterized by the expression of collagens type II, IX, and XII, and aggrecan [4], and when they become hypertrophic, they are characterized by the production of type X collagen. Eventually, terminally differentiated chondrocytes undergo apoptosis and the ECM is mineralized and replaced by bone [5].

In $\mathrm{OA}$, the balance between synthesis and degradation conferred by chondrocytes is lost, resulting in cartilage destruction. Once the osteoarthritic process has begun, phenomena such as proliferation and hypertrophic differentiation of chondrocytes, remodeling, ECM mineralization, and apoptosis also occur [6]. At the onset of OA, the quantity and composition of ECM undergo a change. There is a significantly reduced synthesis of aggrecan and an increase of collagen synthesis, but with a modification in collagen-type composition, changing from collagen type II to collagen type I, which is more characteristic of subchondral bone. To date, it is well-recognized that OA possesses an important inflammatory component. Inflammation is a triggering factor for OA and leads chondrocytes and synovium to produce cytokines such as Interleukin-1Beta (IL-1 $\beta$ ) and Tumor Necrosis Factor $\alpha$ (TNF- $\alpha$ ), among others [7, 8]. These inflammatory cytokines contribute to a catabolic process and favor the synthesis of Matrix Metalloproteinases (MMP) and A Disintegrin And Metalloproteinase Thrombospondin type I Motifs (ADAMTS), with MMP13 and ADAMTS5 the principal collagenase and aggrecanase, respectively $[9,10]$. On the other hand, anabolic cytokines Insulin-like Growth Factor 1 (IGF-1), Transforming Growth Factor $\beta 1$ (TGF- $\beta 1$ ), 2, and 3, Fibroblast Growth Factors (FGF) 2, 4 , and 8 , and BMP stimulate ECM synthesis in an attempt to repair the damage $[7,8]$. However, the degenerative activity of matrix-degrading proteins is enhanced by the increased levels of Nitric Oxide (NO), which is also upregulated by inflammatory cytokines. In turn, NO upregulates the transcriptional activity of the Nuclear Factor kappa-light-chainenhancer of activated Beta cells (NF- $\mathrm{KB})$, maintaining chronic inflammation, mediating apoptosis of chondrocytes and perpetuating articular cartilage damage [7].

\subsection{DNA Methylation}

The most widely studied epigenetic modification in humans is DNA methylation that, in general, is correlated with gene silencing. DNA methylation occurs in $\mathrm{CpG}$ dinucleotides, which are quite rare in the human genome because their frequency is approximately $1 \%$. These dinucleotides are clustered in islands, which are regions with $>200$ bases, with a $\mathrm{CG}$ content of at least $50 \%$, and with an observed, expected $\mathrm{CpG}$ frequency of at least $60 \%(\mathrm{Obs} / \mathrm{Exp} \mathrm{CpG}=[\mathrm{Number}$ of $\mathrm{CpG} /($ Number of $\mathrm{C} \times$ Number of $\mathrm{G})] \mathrm{x} \mathrm{N}$; where $\mathrm{N}$ is the total number of nucleotides in the sequence analyzed). About $70 \%$ of human genome promoters are associated with $\mathrm{CpG}$ islands, of which approximately $94 \%$ remain unmethylated in normal cells [11]. DNA methylation could also occur in regions of lower CpG density that lie in close 
proximity to $\mathrm{CpG}$ islands $(\sim 2 \mathrm{~kb})$ called $\mathrm{CpG}$ island shores, and their methylation is also associated with gene silencing [12].

DNA methylation occurs through the covalent addition of a methyl group to C5 position of Cytosine (C) to form methylated Cytosine $(5 \mathrm{mC})$. This is mediated by DNA Methyltransferases (DNMT) that catalyze the transfer of the methyl group from S-Adenosyl-Methionine (SAM) to the C base (Fig. 1). There are two types of DNMT: de novo and maintenance. DNMT3A and DNMT3B are the de novo DNMT and are those responsible for establishing the pattern of methylation during embryonic development. DNMT1 is the maintenance DNMT and is responsible for maintaining DNA methylation patterns during cell division [13]. DNA methylation can inhibit gene activity directly because the methylation of promoter $\mathrm{CpG}$ islands interferes with the binding of Transcription Factors (TF) to their target sites [14]. DNA methylation can also indirectly promote gene silencing by recruiting the Methyl-CpG-Binding Domain (MBD) proteins that form part of Methyl-CpG-binding Protein (MeCP) complexes [15]. Of particular importance are MeCP1 and $\mathrm{MeCP} 2$, which mediate transcriptional repression by favoring Histone Deacetylase (HDAC) activity, leading to histone deacetylation [16].

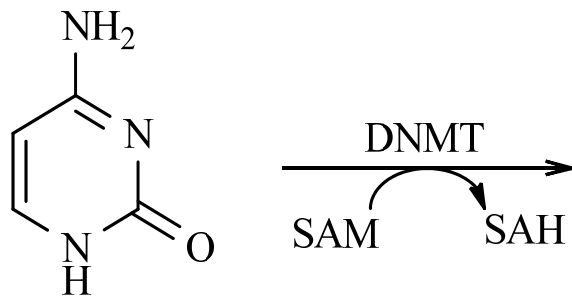

$\mathrm{C}$<smiles>Cc1c[nH]c(=O)nc1N</smiles>

$5 \mathrm{mC}$<smiles>Nc1nc(=O)[nH]cc1O</smiles>

$5 \mathrm{hmC}$

Fig. (1). DNA methylation and DNA hydroxymethylation. DNMTs catalyses the transfer of a methyl group from SAM to the fifth carbon of $\mathrm{C}$ creating $5 \mathrm{mC}$. The methyl group of $5 \mathrm{mC}$ can be modified by the addition of a hydroxyl group mediated by TETs to generate 5-hydroxymethyl-cytosine (5hmC).

DNMTs: DNA methyltransferases; SAM: S-adenosyl methionine; SAH: S-adenosyl homocysteine; C: cytosine; 5mC: 5methylcytosine; 5hmC: 5-hydroxymethyl-cytosine; TETs: ten-eleven translocation cytosine dioxygenases

\subsection{The Role of DNA Methylation in Osteoarthritis}

Several studies have investigated the role of DNA methylation in loci involved in different pathways or molecules related to OA. The most relevant findings are mentioned and (Table 1) provides a summary of the individual genes analyzed.

Table 1. Methylation analysis of individual loci in osteoarthritis.

\begin{tabular}{|c|c|c|c|c|c|c|}
\hline Gene & Cell & Samples & $\begin{array}{l}\text { Methylation } \\
\text { levels }\end{array}$ & $\begin{array}{c}\text { Gene } \\
\text { expression }\end{array}$ & $\begin{array}{c}\text { Strategies for DNA methylation } \\
\text { analysis }\end{array}$ & Ref. \\
\hline \multicolumn{7}{|l|}{ ECM } \\
\hline \multirow{3}{*}{ COL2A1 } & Human chondrocytes & $\begin{array}{l}\text { AC of the knee with no } \\
\text { abnormalities }\end{array}$ & $\mathrm{L}$ & $\downarrow$ & $\begin{array}{c}\text { Restriction enzyme-based method and } \\
\text { DNA bisulfite sequencing }\end{array}$ & [18] \\
\hline & MSC on chondrogenesis & & $\mathrm{L}$ & $\uparrow$ & & \\
\hline & OA chondrocytes & THR vs. \#NOF & $\mathrm{L}$ & $\uparrow$ & Bisulfite pyrosequencing & {$[19]$} \\
\hline COL9A1 & OA chondrocytes & THR vs. \#NOF & $\mathrm{H}$ & $\downarrow$ & Bisulfite pyrosequencing & {$[19]$} \\
\hline \multirow[t]{2}{*}{ COL10A1 } & Human chondrocytes & No cartilage abnormalities & $\mathrm{H}$ & $\downarrow$ & $\begin{array}{c}\text { Restriction enzyme-based method and } \\
\text { DNA bisulfite sequencing }\end{array}$ & [18] \\
\hline & MSC on chondrogenesis & & $\mathrm{L}$ & $\uparrow$ & & \\
\hline$A C A N$ & OA chondrocytes & Not specified & $\mathrm{L}$ & - & & {$[20]$} \\
\hline \multicolumn{7}{|l|}{ Proteases } \\
\hline$M M P 3$ & OA chondrocytes & THR vs. \#NOF & $\mathrm{L}$ & - & Restriction enzyme-based method & {$[21]$} \\
\hline$M M P 9$ & OA chondrocytes & THR vs. \#NOF & $\mathrm{L}$ & - & Restriction enzyme-based method & {$[21]$} \\
\hline
\end{tabular}




\begin{tabular}{|c|c|c|c|c|c|c|}
\hline Gene & Cell & Samples & $\begin{array}{l}\text { Methylation } \\
\text { levels }\end{array}$ & $\begin{array}{c}\text { Gene } \\
\text { expression }\end{array}$ & $\begin{array}{c}\text { Strategies for DNA methylation } \\
\text { analysis }\end{array}$ & Ref. \\
\hline \multirow{3}{*}{$M M P 13$} & OA chondrocytes & THR vs. \#NOF & $\mathrm{L}$ & - & Restriction enzyme-based method & {$[21]$} \\
\hline & OA chondrocytes & THR vs. \#NOF & $\mathrm{L}$ & $\uparrow$ & Bisulfite pyrosequencing & {$[22]$} \\
\hline & OA chondrocytes & THR vs. \#NOF & $\mathrm{L}$ & $\uparrow$ & $\begin{array}{l}\text { Bisulfite sequencing and } \\
\text { pyrosequencing }\end{array}$ & [23] \\
\hline \multirow{2}{*}{ ADAMTS4 } & OA chondrocytes & THR vs. \#NOF & $\mathrm{L}$ & - & Restriction enzyme-based method & {$[21]$} \\
\hline & & THR vs. \#NOF & $\mathrm{L}$ & $\uparrow$ & Restriction enzyme-based method & [24] \\
\hline \multicolumn{7}{|l|}{ Inflammation } \\
\hline \multirow[t]{2}{*}{$I L 1 B$} & Human chondrocytes $^{\mathrm{a}}$ & THR vs. \#NOF & $\mathrm{L}$ & $\uparrow$ & Restriction enzyme-based method & {$[25]$} \\
\hline & OA chondrocytes & THR vs. \#NOF & $\mathrm{L}$ & $\uparrow$ & Bisulfite pyrosequencing & {$[22]$} \\
\hline IL8 & OA chondrocytes & THR vs. \#NOF & $\mathrm{L}$ & $\uparrow$ & Bisulfite pyrosequencing & {$[27]$} \\
\hline SOCS2 & OA chondrocytes & THR vs. \#NOF & $\mathrm{L}$ & $\downarrow$ & Bisulfite pyrosequencing & [29] \\
\hline \multirow[t]{2}{*}{$L E P$} & $\begin{array}{l}\text { Min OA and normal } \\
\text { chondrocytes }\end{array}$ & $\begin{array}{l}\text { THR and TKR vs. Normal } \\
\text { chondrocytes }\end{array}$ & $\mathrm{H}$ & $\downarrow$ & DNA bisulfite sequencing & {$[31]$} \\
\hline & Max OA chondrocytes & & $\mathrm{L}$ & $\uparrow$ & & \\
\hline \multicolumn{7}{|l|}{ ROS-related } \\
\hline SOD2 & OA chondrocytes & THR vs. \#NOF & $\mathrm{H}$ & $\downarrow$ & DNA bisulfite sequencing & {$[33]$} \\
\hline iNOS & OA chondrocytes & THR vs. \#NOF & $\mathrm{L}$ & $\uparrow$ & $\begin{array}{l}\text { Bisulfite sequencing or } \\
\text { pyrosequencing. }\end{array}$ & {$[34]$} \\
\hline \multicolumn{7}{|c|}{ Chondrogenesis } \\
\hline \multirow[b]{2}{*}{$S O X 9$} & MSC on chondrogenesis & Synovium-derived MSC & $\mathrm{L}$ & $\uparrow$ & DNA bisulfite sequencing & [39] \\
\hline & OA chondrocytes & THR vs. \#NOF & $\mathrm{H}$ & $\downarrow$ & $\begin{array}{l}\text { Methylation-specific PCR and } \\
\text { bisulfite sequencing }\end{array}$ & {$[40]$} \\
\hline SOX4 & & Synovium-derived MSC & $\mathrm{L}$ & $\downarrow$ & DNA bisulfite sequencing & [39] \\
\hline$R U N X 2$ & MSC on chondrogenesis & Synovium-derived MSC & $\mathrm{L}$ & $\uparrow$ & DNA bisulfite sequencing & [39] \\
\hline \multicolumn{7}{|c|}{ Growth factors } \\
\hline$B M P 7$ & Human aged chondrocytes & Knee tissue donors & $\mathrm{H}$ & $\downarrow$ & Methylation specific PCR & [42] \\
\hline SOST & OA chondrocytes & TKR vs. Knee fracture & $\mathrm{L}$ & $\uparrow$ & $\begin{array}{l}\text { Methylation-specific PCR and } \\
\text { bisulfite sequencing }\end{array}$ & {$[45]$} \\
\hline GDF5 & Human chondrocytes & CH8 cell line & $\mathrm{L}$ & $\uparrow$ & Bisulfite pyrosequencing & [49] \\
\hline \multicolumn{7}{|l|}{ Other } \\
\hline$p 21^{W A F I / C I P 1}$ & OA chondrocytes & $\begin{array}{l}\text { TKR vs. Normal human } \\
\text { femoral condyles }\end{array}$ & $\mathrm{L}$ & $\downarrow$ & DNA bisulfite sequencing & {$[51]$} \\
\hline $\mathrm{DIO} 2$ & OA chondrocytes & $\begin{array}{l}\text { THR/TKR vs. Preserved } \\
\text { chondrocytes }\end{array}$ & $\mathrm{H}$ & $\uparrow$ & MALDI-TOF mass spectrometry & {$[55]$} \\
\hline
\end{tabular}

L: Low; H: High; ECM: Extracellular Matrix; AC: Articular Cartilage; MSC: Mesenchymal Stem Cells; THR: Total Hip Replacement; TKR: Total Knee Replacement; \#NOF: Fracture of the Neck Of Femur; ${ }^{a}$ Exposed to IL-1 $\beta$ and TNF- $\alpha$; ROS: Reactive Oxygen Species.

\subsubsection{Methylation in ECM genes}

Chick embryo chondrocytes express type II collagen; however, if they dedifferentiate, they cease their synthesis and begin to synthesize type I collagen, which is more typical in fibroblasts. Interestingly, in chick embryo chondrocytes, the Col2al gene exhibits reduced methylation in comparison with that of fibroblasts, but there is no change in methylation status when chondrocytes become dedifferentiated [17]. In human articular chondrocytes and in MSC subjected to chondrogenesis, all of the $74 \mathrm{CpG}$ sites of a region around the Transcription Start Site (TSS) of the COL2A1 gene promoter are unmethylated. However, this does not correlate with COL2A1 expression because, in human articular chondrocytes, gene expression is low, whereas in MSC subjected to chondrogenesis, COL2A1 demonstrates high expression [18]. On the other hand, in chondrocytes from patients with OA and controls, all of the 21 $\mathrm{CpG}$ sites in the COL2A1 enhancer are nearly completely demethylated; however, COL2A1 expression is 9-fold higher in OA chondrocytes in comparison with controls [19]. All of these findings suggest that the regulation of COL2A1 could be independent of DNA methylation of the gene itself.

Type IX collagen is important for the formation of a stable collagen network and for the maintenance of cartilage organization and integrity. COL9A1 gene-expression levels in OA chondrocytes are 6,200-fold lower than in normal chondrocytes, and six of the eight $\mathrm{CpG}$ sites of the COL9A1 promoter are significantly hypermethylated [19]. Human articular chondrocytes are negative for type $\mathrm{X}$ collagen unless they become hypertrophic. In these cells, two CpG sites of COL10A1 are consistently methylated and there is no gene expression. In contrast, in chondrocytes produced from 
$\mathrm{MSC}$, there is reduced methylation at these two $\mathrm{CpG}$ sites, with strong COL10A1 expression [18]. Aggrecan is an essential component of cartilage ECM that is reduced during aging; hence, it is associated with OA development; however, there are no significant changes in methylation levels at the $\mathrm{CpG}$ island of the Aggrecan $(A C A N)$ gene promoter in normal aged or in OA chondrocytes [20]. Thus, it appears that the expression of $A C A N$ is not modulated by changes of methylation in the promoter region.

\subsubsection{Matrix-Degrading Enzyme Genes}

MMP expression in healthy cartilage is low and, in contrast, it is elevated in OA, resulting in ECM degradation. Methylation analysis of the promoter region of $M M P 3, M M P 9$, and $M M P 13$ genes in OA cartilage shows a significant loss of methylation in comparison with normal cartilage. However, not all $\mathrm{CpG}$ sites of these promoter genes are equally susceptible to methylation loss and, for each gene, there is a specific CpG site from TSS where demethylation is more significant: at -635 bp for MMP3; at -36 bp for $M M P 9$, and at -110 bp for MMP13 [21]. In addition, methylation at the -110 bp site for MMP13 decreases the binding of Hypoxia-inducible Factor 2 Alpha (HIF-2 $\alpha$ ), a TF that regulates $M M P 13$ expression [22]. On the other hand, demethylation of another specific region in the MMP13 promoter, the -104 bp site, correlates with increased MMP13 expression and avoids the binding of a TF, the cAMP Response Element Binding (CREB) [23]. ADAMTS5 is considered the major aggrecanase in OA; however, ADAMTS4 also contributes to aggrecan degradation. There is methylation loss at $\mathrm{CpG}$ sites in the ADAMTS4 promoter, but the -753 bp site comprises the most consistently demethylated site, with concomitant, strong ADAMTS4 expression up to 700-fold in the surface zone of OA cartilage [21, 24]. All of this is of interest because previously it was widely thought that the methylation of each $\mathrm{CpG}$ site was required to repress gene expression; however, these findings suggest that methylation of a single site may be sufficient to affect gene expression.

\subsubsection{Inflammation-Related Genes}

Under normal conditions, there is no expression of IL-1 $\beta$ gene $(I L 1 B)$ in human articular chondrocytes; however, when these are experimentally exposed to IL- $1 \beta$ and TNF- $\alpha$ there is a loss of DNA methylation at a specific CpG site (-299 bp) in the promoter and IL1B expression increases 100- to 1,000-fold [25]. Interestingly, in OA chondrocytes, the same IL1B CpG site is demethylated [22], which suggests that inflammatory cytokines can change methylation status at specific $\mathrm{CpG}$ sites during the OA process. Interleukin 8 (IL-8), also known as Chemokine (C-X-C motif) Ligand 8 (CXCL8), is a pro-inflammatory chemokine that mediates the activation and migration of neutrophils into tissue from peripheral blood, as well as the release of MMP13 [26]. In OA chondrocytes, IL 8 expression is considerably high, and its promoter region is significantly demethylated at three CpG sites: $-116 \mathrm{bp}$; $-106 \mathrm{bp}$, and $-31 \mathrm{bp}$, with $-116 \mathrm{bp}$ CpG site the strongest predictor of IL8 expression [27]. Suppressors of Cytokine Signaling proteins (SOCS) are inhibitors of cytokine signaling, and include SOCS1-SOCS7 and Cytokine-Inducible SH2-domain-1 (CIS-1), with SOCS1, SOCS2, SOCS3, and CIS-1 the best characterized of these [28]. The SOCS2 promoter possesses 28 CpG sites in OA chondrocytes; 16 of these $\mathrm{CpG}$ sites, located between -920 and $-641 \mathrm{bp}$, are hypermethylated, while $13 \mathrm{CpG}$ sites, localized between -419 and $-15 \mathrm{bp}$, are demethylated. However, there is no difference in SOCS2 promoter methylation status between OA and normal chondrocytes or in human chondrocytes after cytokine stimulation. On the other hand, the gene expression of SOCS2 is reduced in OA chondrocytes [29], suggesting that this is not regulated due to DNA methylation of the gene itself.

Leptin (LEP) is a cytokine-like peptide secreted by white adipose tissue that can regulate bone growth through collagen synthesis, mineralization, osteoblast proliferation, and the stimulation of endochondral ossification [8]. LEP is directly correlated with the OA grade, and its upregulation increases $M M P 9$ and $M M P 13$ expression [30]. In healthy chondrocytes and in the chondrocytes of minimal OA, LEP promoter is highly methylated with a consequent very low gene expression; this downregulation of $L E P$ exerts an effect on MMP13 expression by reducing its levels significantly, whereas in advanced OA, LEP promoter possesses very low levels of methylation and the gene is highly expressed [31].

\subsubsection{Reactive Oxygen Species-Related Genes}

Chondrocytes express Nicotinamide adenine dinucleotide phosphate-Oxidase (NOX) and Nitric Oxide Synthase (NOS) family members, which generate the Reactive Oxygen Species (ROS): NO and anion superoxide. The increase of NO in articular chondrocytes suppresses energy metabolism, activates MMP, and represses the synthesis of collagen type II and aggrecan in ECM [32]. To prevent damage due to ROS accumulation, chondrocytes produce the Superoxide Dismutase (SOD) enzymes SOD1, SOD2, and SOD3, which are downregulated in OA chondrocytes. In OA cartilage, there is significantly increased methylation at $\mathrm{CpG}$ sites of the SOD2 promoter, with low expression levels of the gene 
[33]. NO production in OA is also the consequence of upregulation of inducible NOS (iNOS), which is activated by IL-1 $\beta$ and TNF- $\alpha$ [34]. In the promoter and enhancer regions of $i N O S$, between -1400 bp and +117 bp from the TSS, there are $13 \mathrm{CpG}$ sites (seven in the promoter, and six in exon 1 nearest to the TSS). Nevertheless, in OA and normal chondrocytes, six of the seven CpG sites of the $i N O S$ promoter are predominantly methylated, and the remaining CpG sites of the promoter closest to the TSS (-289 bp) and the six sites of the exon 1 are demethylated [35]. These data indicate that epigenetic regulation of $i N O S$ in human chondrocytes does not involve the promoter region between -1400 bp and $-117 \mathrm{bp}$.

$i N O S$ expression is regulated by $\mathrm{NF}-\kappa \mathrm{B}$, a signaling factor activated by tissue damage and inflammation. The $i N O S$ enhancer region contains $\mathrm{NF}-\kappa \mathrm{B}$ binding sites, and the $\mathrm{CpG}$ sites of that region in $\mathrm{OA}$ chondrocytes are significantly demethylated. It appears that the loss of methylation at specific CpG sites in the $i N O S$ promoter could not account for its abnormal expression; however, demethylation of specific NF- $\kappa \mathrm{B}$ enhancer elements could explain the increased iNOS expression in OA [35]. Interestingly, glucosamine and an NF- $\kappa \mathrm{B}$ inhibitor inhibit cytokine-induced demethylation at a specific site in the $I L 1 B$ gene promoter, resulting in decreased gene expression [36].

\subsubsection{Transcription Factor Genes}

Sex-determining region Y-box 1 (SOX) belong to a family of TF that carries a characteristic High-Mobility-Group (HMG) domain that binds DNA in a sequence-specific manner [37]. SOX are expressed in all chondrogenic cells, with the exception of hypertrophic chondrocytes, and play a significant role in the maintenance of chondrocytic phenotypes [37]. SOX9 is a key factor for chondrogenesis because it is required for controlling the expression of essential ECM genes, such as COL2A1,COL9A1,COL11A1, and ACAN [37, 38]. Methylation analysis of the promoter region of SOX9 and Runt-related transcription factor 2 (RUNX2) in MSC subjected experimentally to chondrogenesis demonstrates low methylation and increased gene expression, regardless of the differentiation status during chondrogenesis [39], whereas in OA chondrocytes, there is downregulation of SOX9 and promoter methylation is increased, reducing the binding affinity of TF such as CREB and CCAAT-Binding Factor/Nuclear Factor-Y (CBF/NF-Y) [40]. These data indicate that promoter regions of chondrogenesis-related genes SOX9 and RUNX2 are maintained at low levels during chondrogenesis to favor their expression; however, a change in the methylation status of $S O X 9$ promoter could be associated with OA development.

\subsubsection{Growth Factors and Its Antagonists}

Bone Morphogenetic Protein 7 (BMP7), or Osteogenic protein 1 (OP-1), is a member of the TGF- $\beta$ superfamily of regulatory molecules. BMP7 is involved in cartilage maintenance and repair by regulating genes of ECM, of anabolic pathways and of bone formation, as well as genes of regulation of cytokines and of various catabolic pathways responsible for ECM degradation and apoptosis [41]. In aged chondrocytes, a positive correlation between age and methylation of the $B M P 7$ promoter is observed, with concomitant decreased expression of $B M P 7$, as well as of genes regulated by $B M P 7$, such as $I G F-1$, IGF-1 receptor $(I G F-1 R)$, and $A C A N$ [42]. This age-related increased methylation in the $B M P 7$ promoter may contribute to the cartilage loss observed in aging and during the progression of OA. Sclerostin (SOST) is a BMP antagonist that modulates mitogenic activity through sequestering BMP [43]. In OA, SOST promotes subchondral bone sclerosis and inhibits cartilage degradation [44]. In OA chondrocytes, the CpG region of the SOST promoter is hypomethylated and gene expression is upregulated compared with normal chondrocytes. Interestingly, demethylation of the gene promoter favors Smad 1/5/8 binding, increasing the expression of SOST [45].

Growth Differentiation Factor 5 (GDF5) is also a member of the TGF- $\beta$ superfamily and is implicated in chondrogenesis and in chondrocyte proliferation [46]. A Single Nucleotide Polymorphism (SNP) located in the 5'Untranslated Region (5'UTR) of the GDF5 gene, the rs $143383(\mathrm{C} / \mathrm{T})$, is strongly associated with OA and exerts a functional effect [47]. In OA chondrocytes, the OA-risk T allele exhibits lower expression of the gene than that of the C allele, a phenomenon known as Differential Allelic Expression (DAE) [48]. The effect of rs143383 is dependent on a second SNP also localized within the 5'UTR of GDF5, the rs $143384(\mathrm{C} / \mathrm{T})$, and decreased expression of the T allele of rs143383 is only observed in individuals who are compound heterozygous for both SNP. In cell lines and joint tissues, there is demethylation of GDF5 correlating with its increased expression, and interestingly, CpG sites formed by the C alleles of both SNP are variably methylated, and demethylation of the heterozygous cell line increases the DAE imbalance between $\mathrm{C}$ and $\mathrm{T}$ alleles [49]. This indicates that the DAE variability, thus the OA susceptibility conferred by rs 143383, is regulated by DNA methylation. 


\subsubsection{Other Genes}

Similar findings to those for SOCS2 are found in the Cyclin-dependent kinase inhibitor $1\left(p 21^{W A F I / C I P I}\right)$ gene; this is not an inflammation-related gene, but an inhibitor of cell proliferation that is highly expressed in non-proliferating chondrocytes [50]. In OA chondrocytes, $p 21^{\text {WAFI/CIPI }}$ is downregulated regardless of its promoter methylation status [51]; thus, it appears that at least in chondrocytes, its downregulation is not due to hypermethylation of the promoter.

The Deionidase Iodothyronine type 2 (DIO2) gene encodes a selenoprotein that catalyzes the conversion of an inactive thyroid hormone (T4) to its active form (T3). T3 drives the terminal maturation of growth plate chondrocytes, leading to cell hypertrophy, ECM destruction and mineralization, and the formation of bone [52]. Two SNPs of DIO2 have been associated with OA, with a protective association conferred by the T allele of rs12885300 (T/C), and a clear, predisposing association with the $\mathrm{C}$ allele of rs225014 (C/T) and with the haplotype C-C formed by these two SNP [53]. DIO2 also exhibits DAE, with the OA-risk $\mathrm{C}$ allele more abundantly present in articular joint tissues than the $\mathrm{T}$ allele [54]. In the methylation analysis of DIO2, a CpG site $2031 \mathrm{bp}$ upstream of the TSS is methylated in OA cartilage, with a surprisingly positive association between methylation and DIO2 expression. This effect appears to be driven by the risk $\mathrm{C}$ allele, because the homozygosity and heterozygosity for this allele show hypermethylation at the CpG $2031 \mathrm{bp}$ site with increased expression of $\mathrm{DIO}$, while in the homozygous $\mathrm{T}$ allele, there are no differences in methylation or gene expression [55]. This positive correlation between methylation and DIO2 expression in articular cartilage among carriers of the rs 225014 OA-risk C allele does not act in accordance with the typical inverse relationship between $\mathrm{CpG}$ methylation and gene expression.

\subsubsection{Other Cytosine Modifications}

Most studies have explored the role of $\mathrm{C}$ methylation; however, recently a role for 5-hydroxymethylcytosine $(5 \mathrm{hmC})$ as an epigenetic mark has been described. The Ten-eleven translocation cytosine dioxygenases (TET) comprise TET1, TET2, and TET3. These proteins catalyze $5 \mathrm{mC}$ oxidation and generate $5 \mathrm{mC}$ derivatives, including $5 \mathrm{hmC}$, which is stably present in the majority of tissues and might function as an epigenetic mark (Fig. 1) [56]. A recent study demonstrated a global increase in $5 \mathrm{hmC}$ levels up to 5-6-fold in OA chondrocytes, and locus-specific analysis showed a significant increase of $5 \mathrm{hmC}$ content in $M M P 1$ and $M M P 3$ promoters. With regard to TET proteins, there are no differences in TET2 and TET3 expression, but surprisingly, significant downregulation of TET1 is observed in OA chondrocytes, as well as in normal chondrocytes exposed to IL-1 $\beta$ and TNF- $\alpha$ [57]. It is surprising that significant downregulation of TET1 is concomitant to an increase in $5 \mathrm{hmC}$ in OA chondrocytes, considering that a loss of TET1 in some cancers leads to an opposite effect: a global loss of 5hmC [58]. These observations suggest that the increase in $5 \mathrm{hmC}$ and downregulation of TET1 demonstrate clear perturbation of $5 \mathrm{hmC}$ homeostasis in OA chondrocytes.

\subsubsection{Genome-wide Methylation Analyses}

Lately, genome-wide methylation and genome-wide 5-hydroxymethylation profiles in OA have been developed with very interesting results (Table 2) [59 - 66]. The main findings of these studies can be summarized as follows: 1) OA can be distinguished undoubtedly from controls according to their DNA methylation profile; 2) OA of the hip and the knee possesses different DNA methylation profiles; 3) Differentially Methylated Regions (DMR) are represented more consistently in genes participating in TGF- $\beta$ signaling, developmental pathways (specifically the homeobox family of TF), inflammation, and ECM degradation pathways; 4) Differentially Methylated Loci (DML) more consistently include $R U N X 1$, genes associated with the degradation of ECM (ADAMTS and MMP), and genes that are members of the TGF- $\beta$ signaling pathway (ACRV1B, SMAD2, SMAD3, TGFBR2, TGFB1, and BMP6); 5) there are DMR between OA and patients with Osteoporosis (OP), with an inverse methylation relationship of methylation in both groups; 6) OA can be differentiated from controls according to their 5-hydroxymethylome, observing a global increase of $5 \mathrm{hmC}$, at least for OA of the knee, and 7) Differentially hydroxymethylated Regions (DhMR) are related to Wntsignaling and bone-remodeling pathways, as well as with genes previously related to OA (MMP3, GDF5, and COL11A1).

Table 2. Genome-wide methylome and genome-wide 5-hydroxymethylome profiles in osteoarthritis.

\begin{tabular}{|c|c|c|c|c|c|}
\hline \multirow{2}{*}{ Sample (n) } & \multirow{2}{*}{$\begin{array}{c}\text { CpG sites } \\
\text { analyzed }\end{array}$} & All & Hyper-methylated & Hypo-methylated & \multirow{2}{*}{ Gene Ontology Analysis } \\
\cline { 3 - 5 } & $>27,000$ & 241 & 217 & 24 & $\begin{array}{c}\text { Homeobox superfamily of TF (HOXA9, IRX2, } \\
\text { MSX2) and genes of cell differentiation }\end{array}$ \\
\hline $\begin{array}{c}\text { THR and Osteoporotic hip } \\
\text { (26 vs. 27) }\end{array}$ & [59] \\
\hline
\end{tabular}


(Table 2) contd.....

\begin{tabular}{|c|c|c|c|c|c|c|}
\hline \multirow{2}{*}{ Sample $(n)$} & \multirow{2}{*}{$\begin{array}{l}\text { CpG sites } \\
\text { analyzed }\end{array}$} & \multicolumn{3}{|c|}{ DML } & \multirow{2}{*}{ Gene Ontology Analysis a } & \multirow{2}{*}{ Ref. } \\
\hline & & All & Hyper-methylated & Hypo-methylated & & \\
\hline $\begin{array}{l}\text { TKR and Healthy controls } \\
\text { ( } 25 \text { vs. } 20)\end{array}$ & $>27,000$ & 91 & 54 & 37 & $\begin{array}{c}\text { Inflammation and Regulation of transcriptional } \\
\text { activity-related genes and } R U N X 1 \text { and } M S X 1 \text { genes }\end{array}$ & {$[60]$} \\
\hline $\begin{array}{l}\text { THR, TKR and \#NOF } \\
(23 / 73 \text { vs } 21)\end{array}$ & $>485,000$ & & & & & {$[61]$} \\
\hline THR vs. \#NOF & & 5,322 & 2,669 & 2,653 & $\begin{array}{c}\text { Degradation of ECM, anabolic/catabolic pathway of } \\
\text { cartilage homeostasis, TGF- } \beta \text { pathway }\end{array}$ & \\
\hline THR Cluster1 vs. Cluster $2^{c}$ & & 15,239 & 8,524 & 6,915 & $\begin{array}{l}\text { Inflammation, Cartilage degradation, and TGF- } \beta \\
\text { pathways }\end{array}$ & \\
\hline TKR Cluster1 vs. Cluster $2^{\mathrm{c}}$ & & 5,769 & 3,000 & 2,769 & Immune response & \\
\hline THR vs. TKR & & 5,547 & 2,598 & 2,949 & $\begin{array}{l}\text { Genes involved in OA pathogenesis (ADAM12, } \\
\qquad A D A M T S 5, G D F 5)\end{array}$ & \\
\hline $\begin{array}{l}\text { THR } \\
(24)\end{array}$ & & & & & & {$[62]$} \\
\hline OA vs. Intact cartilage & $>485,000$ & 550 & 172 & 378 & TGF- $\beta$ pathway genes and $R U N X 1$ and $F U R I N$ & \\
\hline $\begin{array}{l}\text { TKR } \\
(15)\end{array}$ & $\sim 244,000$ & 1,214 & 1,070 & 144 & TGF- $\beta$ and WNT pathways & [63] \\
\hline Severe OA vs. Mild OA ${ }^{d}$ & & & & & $\begin{array}{l}\text { Hypermethylation of genes related with TGF- } \beta \\
(B M P 2, B M P 4, M A P K 3, S M A D)\end{array}$ & \\
\hline TKR vs. THR & & 6,272 & & & $\begin{array}{l}\text { Developmental pathways (limb development and } \\
\text { skeletal system morphogenesis) }\end{array}$ & [64] \\
\hline $\begin{array}{c}\text { Damaged vs. Undamaged } \\
\text { cartilage } \\
(14 \text { vs. } 17)\end{array}$ & & & & & Homeobox (HOX) cluster & \\
\hline $\begin{array}{l}\text { TKR, THR, and controls } \\
(5,6 \text {, and } 7)\end{array}$ & $>485,000$ & & & & $\begin{array}{l}\text { Skeletal and embryonic organ system development } \\
\text { and Homeobox (HOX) }\end{array}$ & {$[65]$} \\
\hline TKR vs. Controls & & 72 & & & & \\
\hline THR vs. Controls & & 26 & & & & \\
\hline TKR/THR vs. Controls & & 103 & & & & \\
\hline THR vs. TKR & & 67 & & & & \\
\hline After removing overlaps & & 239 & 112 & 127 & & \\
\hline \multirow[t]{3}{*}{$\begin{array}{l}\text { TKR vs. Ligament } \\
\text { reconstruction } \\
(4 \text { vs. } 4)\end{array}$} & & $70,591^{\mathrm{e}}$ & $44,288^{\mathrm{f}}$ & $26,303^{\mathrm{g}}$ & $\begin{array}{c}\text { Increased DhMR in Wnt-signalling and bone- } \\
\text { remodeling pathways }\end{array}$ & [66] \\
\hline & & & & & $\begin{array}{l}\text { Loss of DhMR in cell adhesion, skeletal muscle } \\
\text { development }\end{array}$ & \\
\hline & & & & & $\begin{array}{c}\text { Gene expression change in MMpP3, MMP13 and } \\
\text { inflammation-related genes }\end{array}$ & \\
\hline
\end{tabular}

DML: Differential Methylated Loci; THR: Total Hip Replacement; TKR: Total Knee Replacement; NOF\#: Neck of Femur fracture. a: The main results are presented b: Obtained at autopsy from cadavers with no macroscopic signs of OA c: Defined according to unsupervised hierarchical analysis d: Damaged or undamaged cartilage was assessed macroscopically e: Differentially hydroxyMethylated Regions (DhMR) f: Hyper-5hydroxymethyated g: Hypo-5-hydroxymethyated.

\section{CONCLUSION}

Analysis of DNA methylation in individual loci in OA chondrocytes has shown the expected correlation between methylation levels and gene expression; however, there are exceptions to this rule, such as the COL2A1, SOCS2, and $p 21^{\text {WAFICIPI }}$ genes, in which, despite low methylation levels, gene expression is also decreased. This suggests that, at least for these genes, demethylation is not sufficient to inactivate gene expression, and that several factors could be acting to favor this, for instance, the following: 1) the methylation state of other $\mathrm{CpG}$ sites in the islands or even in the island shores of these loci; 2) the role of other epigenetic mechanisms in transcriptional repression, such as histone modifications, chromatin remodeling, and miRNA, in that they are not mutually exclusive [67], and 3) the method employed to assess DNA methylation because, in several studies, the method was different and this could confer variations on the results (Table 1).

According to the findings of genome-wide methylation analyses, $\mathrm{OA}$ is differentially methylated in comparison with controls; however; there is evidence that OA of the hip and of the knee possess different epigenetic signatures. The comparison between OA of the knee and of the hip has revealed several differentially methylated loci, and the gene ontology analysis of those genes expose the preponderance of developmental pathways (i.e., skeletal system 
morphogenesis) and $H O X$ genes $[61,64,65]$. The latter comprise a highly conserved cluster of genes that encode transcription factors of embryonic development that regulate limb morphogenesis and skeletal formation [68]. The location-specific expression of $H O X$ genes might contribute to defining joint-specific biology and suggests that there may be unique pathways that distinguish OA of the knee from OA of the hip. In this regard, it has been described that OA of the knee and of the hip has also different genetic associations [69]. These findings indicate that OA-associated signals are often joint-specific, and it can be proposed that at least these OA types could be considered as two different entities.

Since OA possesses distinctive methylation profiles, DNA methylation profiling could be a useful diagnostic tool, allowing for the identification not only of OA, but also to differentiate knee samples from hip samples, emphasizing the importance of separating the study of OA by anatomical site. On the other hand, several genes involved in OA- specific pathways are differentially methylated may offer potential therapeutic targets. For example, it is well-recognized that IL-1 $\beta$ is implicated in the pathogenesis and progression of OA with an associated $\mathrm{CpG}$ demethylation in its gene promoter $[35,38]$. Interestingly, in human chondrocyte cultures, it was demonstrated that glucosamine can prevent cytokine-induced demethylation at the $-256 \mathrm{CpG}$ site of $I L 1 B$ promoter with a consequent decreased expression of IL-1 $\beta$ [70], suggesting that modification of DNA methylation is a potential therapeutic strategy for intervening in the OA process. Although further evidence is required to confirm these results, this sheds light on advances for future therapeutic approaches to the disease.

Finally, the recent development of genome-wide hydroxymethylation analysis has made evident the role of another epigenetic mark, the $5 \mathrm{hmC}$ [66], the so-called sixth base, the role of which should be further analyzed in OA.

\section{CONSENT FOR PUBLICATION}

Not applicable.

\section{CONFLICT OF INTEREST}

The author declares no conflict of interest, financial or otherwise.

\section{ACKNOWLEDGEMENT}

This work was financially supported by grant No. 180720 of the Consejo Nacional de Ciencia y Tecnología (CONACyT- Mexico City).

\section{REFERENCES}

[1] Goldring MB, Goldring SR. Articular cartilage and subchondral bone in the pathogenesis of osteoarthritis. Ann N Y Acad Sci 2010; 1192: $230-7$.

[http://dx.doi.org/10.1111/j.1749-6632.2009.05240.x] [PMID: 20392241]

[2] Valdes AM, Spector TD. The contribution of genes to osteoarthritis. Rheum Dis Clin North Am 2008; 34 (3): $581-603$. [http://dx.doi.org/10.1016/j.rdc.2008.04.008] [PMID: 18687274]

[3] Tammen SA, Friso S, Choi SW. Epigenetics: The link between nature and nurture. Mol Aspects Med 2013; $34(4): 753-64$. [http://dx.doi.org/10.1016/j.mam.2012.07.018] [PMID: 22906839]

[4] Martel-Pelletier J, Boileau C, Pelletier JP, Roughley PJ. Cartilage in normal and osteoarthritis conditions. Best Pract Res Clin Rheumatol 2008; 22(2): 351-84.

[http://dx.doi.org/10.1016/j.berh.2008.02.001] [PMID: 18455690]

[5] Michigami T. Current understanding on the molecular basis of chondrogenesis. Clin Pediatr Endocrinol 2014; $23(1): 1-8$. [http://dx.doi.org/10.1297/cpe.23.1] [PMID: 24532955]

[6] Zhong L, Huang X, Karperien M, Post JN. The regulatory role of signaling crosstalk in hypertrophy of MSCs and human articular chondrocytes. Int J Mol Sci 2015; 16(8): 19225-47.

[http://dx.doi.org/10.3390/ijms160819225] [PMID: 26287176]

[7] Maldonado M, Nam J. The role of changes in extracellular matrix of cartilage in the presence of inflammation on the pathology of osteoarthritis. BioMed Res Int 2013; 2013: 284873. [http://dx.doi.org/10.1155/2013/284873] [PMID: 24069595]

[8] Sokolove J, Lepus CM. Role of inflammation in the pathogenesis of osteoarthritis: latest findings and interpretations. Ther Adv Musculoskelet Dis 2013; 5(2): 77-94.

[http://dx.doi.org/10.1177/1759720X12467868] [PMID: 23641259]

[9] Knapinska A, Fields GB. Chemical biology for understanding matrix metalloproteinase function. ChemBioChem 2012; 13(14): 2002-20. [http://dx.doi.org/10.1002/cbic.201200298] [PMID: 22933318] 
[10] Verma P, Dalal K. ADAMTS-4 and ADAMTS-5: Key enzymes in osteoarthritis. J Cell Biochem 2011; $112(12): 3507-14$. [http://dx.doi.org/10.1002/jcb.23298] [PMID: 21815191]

[11] Deaton AM, Bird A. CpG islands and the regulation of transcription. Genes Dev 2011; 25(10): 1010-22. [http://dx.doi.org/10.1101/gad.2037511] [PMID: 21576262]

[12] Irizarry RA, Ladd-Acosta C, Wen B, et al. The human colon cancer methylome shows similar hypo- and hypermethylation at conserved tissue-specific CpG island shores. Nat Genet 2009; 41(2): 178-86. [http://dx.doi.org/10.1038/ng.298] [PMID: 19151715]

[13] Golbabapour S, Abdulla MA, Hajrezaei M. A concise review on epigenetic regulation: insight into molecular mechanisms. Int J Mol Sci 2011; 12(12): 8661-94. [http://dx.doi.org/10.3390/ijms12128661] [PMID: 22272098]

[14] Esteller M. Epigenetic gene silencing in cancer: the DNA hypermethylome. Hum Mol Genet 2007; 16(Spec No 1): R50-9. [http://dx.doi.org/10.1093/hmg/ddm018] [PMID: 17613547]

[15] López-Serra L, Esteller M. Proteins that bind methylated DNA and human cancer: Reading the wrong words. Br J Cancer 2008; 98(12): 1881-5. [http://dx.doi.org/10.1038/sj.bjc.6604374] [PMID: 18542062]

[16] Zlatanova J. MeCP2: The chromatin connection and beyond. Biochem Cell Biol 2005; 83(3): 251-62. [http://dx.doi.org/10.1139/o05-048] [PMID: 15959553]

[17] Fernández MP, Young MF, Sobel ME. Methylation of type II and type I collagen genes in differentiated and dedifferentiated chondrocytes. J Biol Chem 1985; 260(4): 2374-8. [PMID: 2579068]

[18] Zimmermann P, Boeuf S, Dickhut A, Boehmer S, Olek S, Richter W. Correlation of COL10A1 induction during chondrogenesis of mesenchymal stem cells with demethylation of two CpG sites in the COL10A1 promoter. Arthritis Rheum 2008; 58(9): $2743-53$. [http://dx.doi.org/10.1002/art.23736] [PMID: 18759285]

[19] Imagawa K, de Andrés MC, Hashimoto K, et al. Association of reduced type IX collagen gene expression in human osteoarthritic chondrocytes with epigenetic silencing by DNA hypermethylation. Arthritis Rheumatol 2014; 66(11): 3040-51. [http://dx.doi.org/10.1002/art.38774] [PMID: 25048791]

[20] Pöschl E, Fidler A, Schmidt B, Kallipolitou A, Schmid E, Aigner T. DNA methylation is not likely to be responsible for aggrecan down regulation in aged or osteoarthritic cartilage. Ann Rheum Dis 2005; 64(3): 477-80. [http://dx.doi.org/10.1136/ard.2004.022509] [PMID: 15708898]

[21] Roach HI, Yamada N, Cheung KS, et al. Association between the abnormal expression of matrix-degrading enzymes by human osteoarthritic chondrocytes and demethylation of specific CpG sites in the promoter regions. Arthritis Rheum 2005; 52(10): 3110-24. [http://dx.doi.org/10.1002/art.21300] [PMID: 16200590]

[22] Hashimoto K, Otero M, Imagawa K, et al. Regulated transcription of human matrix metalloproteinase 13 (MMP13) and interleukin-1 $\beta$ (IL1B) genes in chondrocytes depends on methylation of specific proximal promoter CpG sites. J Biol Chem 2013; $288(14): 10061-72$. [http://dx.doi.org/10.1074/jbc.M112.421156] [PMID: 23417678]

[23] Bui C, Barter MJ, Scott JL, et al. cAMP response element-binding (CREB) recruitment following a specific CpG demethylation leads to the elevated expression of the matrix metalloproteinase 13 in human articular chondrocytes and osteoarthritis. FASEB J 2012; 26(7): 3000-11. [http://dx.doi.org/10.1096/fj.12-206367] [PMID: 22505473]

[24] Cheung KS, Hashimoto K, Yamada N, Roach HI. Expression of ADAMTS-4 by chondrocytes in the surface zone of human osteoarthritic cartilage is regulated by epigenetic DNA de-methylation. Rheumatol Int 2009; 29(5): 525-34. [http://dx.doi.org/10.1007/s00296-008-0744-z] [PMID: 18941754]

[25] Hashimoto K, Oreffo ROC, Gibson MB, Goldring MB, Roach HI. DNA demethylation at specific CpG sites in the IL1B promoter in response to inflammatory cytokines in human articular chondrocytes. Arthritis Rheum 2009; 60(11): 3303-13. [http://dx.doi.org/10.1002/art.24882] [PMID: 19877066]

[26] Chauffier K, Laiguillon MC, Bougault C, et al. Induction of the chemokine IL-8/Kc by the articular cartilage: Possible influence on osteoarthritis. Joint Bone Spine 2012; 79(6): 604-9. [http://dx.doi.org/10.1016/j.jbspin.2011.12.013] [PMID: 22342065]

[27] Takahashi A, de Andrés MC, Hashimoto K, Itoi E, Oreffo RO. Epigenetic regulation of interleukin-8, an inflammatory chemokine, in osteoarthritis. Osteoarthritis Cartilage 2015; 23(11): 1946-54 [http://dx.doi.org/10.1016/j.joca.2015.02.168] [PMID: 26521741]

[28] Rico-Bautista E, Flores-Morales A, Fernández-Pérez L. Suppressor of cytokine signaling (SOCS) 2, a protein with multiple functions. Cytokine Growth Factor Rev 2006; 17(6): 431-9. [http://dx.doi.org/10.1016/j.cytogfr.2006.09.008] [PMID: 17070092]

[29] de Andrés MC, Imagawa K, Hashimoto K, et al. Suppressors of cytokine signalling (SOCS) are reduced in osteoarthritis. Biochem Biophys Res Commun 2011; 407(1): 54-9. [http://dx.doi.org/10.1016/j.bbrc.2011.02.101] [PMID: 21352802] 
[30] Honsawek S, Chayanupatkul M. Correlation of plasma and synovial fluid adiponectin with knee osteoarthritis severity. Arch Med Res 2010; 41(8): 593-8.

[http://dx.doi.org/10.1016/j.arcmed.2010.11.007] [PMID: 21199727]

[31] Iliopoulos D, Malizos KN, Tsezou A. Epigenetic regulation of leptin affects MMP-13 expression in osteoarthritic chondrocytes: Possible molecular target for osteoarthritis therapeutic intervention. Ann Rheum Dis 2007; 66(12): 1616-21.

[http://dx.doi.org/10.1136/ard.2007.069377] [PMID: 17502362]

[32] Taskiran D, Stefanovic-Racic M, Georgescu H, Evans C. Nitric oxide mediates suppression of cartilage proteoglycan synthesis by interleukin-1. Biochem Biophys Res Commun 1994; 200(1): 142-8.

[http://dx.doi.org/10.1006/bbrc.1994.1426] [PMID: 7513156]

[33] Scott JL, Gabrielides C, Davidson RK, et al. Superoxide dismutase downregulation in osteoarthritis progression and end-stage disease. Ann Rheum Dis 2010; 69(8): 1502-10. [http://dx.doi.org/10.1136/ard.2009.119966] [PMID: 20511611]

[34] de Andrés MC, Maneiro E, Martín MA, Arenas J, Blanco FJ. Nitric oxide compounds have different effects profiles on human articular chondrocyte metabolism. Arthritis Res Ther 2013; 15(5): R115. [http://dx.doi.org/10.1186/ar4295] [PMID: 24025112]

[35] de Andrés MC, Imagawa K, Hashimoto K, et al. Loss of methylation in CpG sites in the NF-kappaB enhancer elements of iNOS is responsible for gene induction in human articular chondrocytes. Arthritis Rheum 2013; 65: 732-42. [http://dx.doi.org/10.1002/art.37806] [PMID: 23239081]

[36] Imagawa K, de Andrés MC, Hashimoto K, et al. The epigenetic effect of glucosamine and a nuclear factor-kappa B (NF-kB) inhibitor on primary human chondrocytes-implications for osteoarthritis. Biochem Biophys Res Commun 2011; 405(3): 362-7. [http://dx.doi.org/10.1016/j.bbrc.2011.01.007] [PMID: 21219853]

[37] Im GI, Kim HJ. Electroporation-mediated gene transfer of SOX trio to enhance chondrogenesis in adipose stem cells. Osteoarthritis Cartilage 2011; 19(4): 449-57.

[http://dx.doi.org/10.1016/j.joca.2011.01.005] [PMID: 21251990]

[38] Goldring MB, Tsuchimochi K, Ijiri K. The control of chondrogenesis. J Cell Biochem 2006; 97(1): 33-44. [http://dx.doi.org/10.1002/jcb.20652] [PMID: 16215986]

[39] Ezura Y, Sekiya I, Koga H, Muneta T, Noda M. Methylation status of CpG islands in the promoter regions of signature genes during chondrogenesis of human synovium-derived mesenchymal stem cells. Arthritis Rheum 2009; 60(5): 1416-26.

[http://dx.doi.org/10.1002/art.24472] [PMID: 19404940]

[40] Kim KI, Park YS, Im GI. Changes in the epigenetic status of the SOX-9 promoter in human osteoarthritic cartilage. J Bone Miner Res 2013; 28(5): 1050-60.

[http://dx.doi.org/10.1002/jbmr.1843] [PMID: 23225119]

[41] Chubinskaya S, Otten L, Soeder S, et al. Regulation of chondrocyte gene expression by osteogenic protein-1. Arthritis Res Ther 2011; 13(2): R55.

[http://dx.doi.org/10.1186/ar3300] [PMID: 21447156]

[42] Loeser RF, Im HJ, Richardson B, Lu Q, Chubinskaya S. Methylation of the OP-1 promoter: Potential role in the age-related decline in OP-1 expression in cartilage. Osteoarthritis Cartilage 2009; 17(4): 513-7.

[http://dx.doi.org/10.1016/j.joca.2008.08.003] [PMID: 18829350]

[43] Winkler DG, Sutherland MK, Geoghegan JC, et al. Osteocyte control of bone formation via sclerostin, a novel BMP antagonist. EMBO J 2003; $22(23): 6267-76$. [http://dx.doi.org/10.1093/emboj/cdg599] [PMID: 14633986]

[44] Chan BY, Fuller ES, Russell AK, et al. Increased chondrocyte sclerostin may protect against cartilage degradation in osteoarthritis. Osteoarthritis Cartilage 2011; 19(7): 874-85.

[http://dx.doi.org/10.1016/j.joca.2011.04.014] [PMID: 21619935]

[45] Papathanasiou I, Kostopoulou F, Malizos KN, Tsezou A. DNA methylation regulates sclerostin (SOST) expression in osteoarthritic chondrocytes by bone morphogenetic protein 2 (BMP-2) induced changes in Smads binding affinity to the CpG region of SOST promoter. Arthritis Res Ther 2015; 17: 160 .

[http://dx.doi.org/10.1186/s13075-015-0674-6] [PMID: 26071314]

[46] Buxton P, Edwards C, Archer CW, Francis-West P. Growth/differentiation factor-5 (GDF-5) and skeletal development. J Bone Joint Surg Am 2001; 83-A(Pt 1)(Suppl. 1): S23-30.

[PMID: 11263662]

[47] Miyamoto Y, Mabuchi A, Shi D, et al. A functional polymorphism in the 5' UTR of GDF5 is associated with susceptibility to osteoarthritis. Nat Genet 2007; 39(4): 529-33. [http://dx.doi.org/10.1038/2005] [PMID: 17384641]

[48] Southam L, Rodríguez-López J, Wilkins JM, et al. An SNP in the 5'-UTR of GDF5 is associated with osteoarthritis susceptibility in Europeans and with in vivo differences in allelic expression in articular cartilage. Hum Mol Genet 2007; 16(18): 2226-32. [http://dx.doi.org/10.1093/hmg/ddm174] [PMID: 17616513] 
[49] Reynard LN, Bui C, Canty-Laird EG, Young DA, Loughlin J. Expression of the osteoarthritis-associated gene GDF5 is modulated epigenetically by DNA methylation. Hum Mol Genet 2011; 20(17): 3450-60. [http://dx.doi.org/10.1093/hmg/ddr253] [PMID: 21642387]

[50] Aigner T, Hemmel M, Neureiter D, et al. Apoptotic cell death is not a widespread phenomenon in normal aging and osteoarthritis human articular knee cartilage: a study of proliferation, programmed cell death (apoptosis), and viability of chondrocytes in normal and osteoarthritic human knee cartilage. Arthritis Rheum 2001; 44(6): 1304-12. [http://dx.doi.org/10.1002/1529-0131(200106)44:6<1304::AID-ART222>3.0.CO;2-T] [PMID: 11407689]

[51] Sesselmann S, Söder S, Voigt R, Haag J, Grogan SP, Aigner T. DNA methylation is not responsible for p21WAF1/CIP1 down-regulation in osteoarthritic chondrocytes. Osteoarthritis Cartilage 2009; 17(4): 507-12. [http://dx.doi.org/10.1016/j.joca.2008.09.006] [PMID: 18954998]

[52] Ohba K, Yoshioka T, Muraki T. Identification of two novel splicing variants of human type II iodothyronine deiodinase mRNA. Mol Cell Endocrinol 2001; 172(1-2): 169-75.

[http://dx.doi.org/10.1016/S0303-7207(00)00368-3] [PMID: 11165050]

[53] Meulenbelt I, Min JL, Bos S, et al. Identification of DIO2 as a new susceptibility locus for symptomatic osteoarthritis. Hum Mol Genet 2008; 17(12): 1867-75. [http://dx.doi.org/10.1093/hmg/ddn082] [PMID: 18334578]

[54] Bos SD, Bovée JV, Duijnisveld BJ, et al. Increased type II deiodinase protein in OA-affected cartilage and allelic imbalance of OA risk polymorphism rs225014 at DIO2 in human OA joint tissues. Ann Rheum Dis 2012; 71(7): 1254-8. [http://dx.doi.org/10.1136/annrheumdis-2011-200981] [PMID: 22492780]

[55] Bomer N, den Hollander W, Ramos YF, et al. Underlying molecular mechanisms of DIO2 susceptibility in symptomatic osteoarthritis. Ann Rheum Dis 2015; 74(8): 1571-9.

[http://dx.doi.org/10.1136/annrheumdis-2013-204739] [PMID: 24695009]

[56] Tan L, Shi YG. Tet family proteins and 5-hydroxymethylcytosine in development and disease. Development 2012; 139(11): $1895-902$. [http://dx.doi.org/10.1242/dev.070771] [PMID: 22569552]

[57] Taylor SE, Smeriglio P, Dhulipala L, Rath M, Bhutani N. A global increase in 5-hydroxymethylcytosine levels marks osteoarthritic chondrocytes. Arthritis Rheumatol 2014; 66(1): 90-100. [http://dx.doi.org/10.1002/art.38200] [PMID: 24449578]

[58] Hsu CH, Peng KL, Kang ML, et al. TET1 suppresses cancer invasion by activating the tissue inhibitors of metalloproteinases. Cell Reports 2012; 2(3): 568-79. [http://dx.doi.org/10.1016/j.celrep.2012.08.030] [PMID: 22999938]

[59] Delgado-Calle J, Fernández AF, Sáinz J, et al. Genome-wide profiling of bone reveals differentially methylated regions in osteoporosis and osteoarthritis. Arthritis Rheum 2013; 65(1): 197-205. [http://dx.doi.org/10.1002/art.37753] [PMID: 23124911]

[60] Fernández-Tajes J, Soto-Hermida A, Vázquez-Mosquera ME, et al. Genome-wide DNA methylation analysis of articular chondrocytes reveals a cluster of osteoarthritic patients. Ann Rheum Dis 2014; 73(4): 668-77. [http://dx.doi.org/10.1136/annrheumdis-2012-202783] [PMID: 23505229]

[61] Rushton MD, Reynard LN, Barter MJ, et al. Characterization of the cartilage DNA methylome in knee and hip osteoarthritis. Arthritis Rheumatol 2014; 66(9): 2450-60. [http://dx.doi.org/10.1002/art.38713] [PMID: 24838673]

[62] Jeffries MA, Donica M, Baker LW, et al. Genome-wide DNA methylation study identifies significant epigenomic changes in osteoarthritic cartilage. Arthritis Rheumatol 2014; 66(10): 2804-15. [http://dx.doi.org/10.1002/art.38762] [PMID: 24980887]

[63] Moazedi-Fuerst FC, Hofner M, Gruber G, et al. Epigenetic differences in human cartilage between mild and severe OA. J Orthop Res 2014; 32(12): 1636-45. [http://dx.doi.org/10.1002/jor.22722] [PMID: 25212754]

[64] den Hollander W, Ramos YF, Bos SD, et al. Knee and hip articular cartilage have distinct epigenomic landscapes: Implications for future cartilage regeneration approaches. Ann Rheum Dis 2014; 73(12): 2208-12. [http://dx.doi.org/10.1136/annrheumdis-2014-205980] [PMID: 25261579]

[65] Aref-Eshghi E, Zhang Y, Liu M, et al. Genome-wide DNA methylation study of hip and knee cartilage reveals embryonic organ and skeletal system morphogenesis as major pathways involved in osteoarthritis. BMC Musculoskelet Disord 2015; 16: 287. [http://dx.doi.org/10.1186/s12891-015-0745-5] [PMID: 26453558]

[66] Taylor SE, Li YH, Wong WH, Bhutani N. Genome-wide mapping of DNA hydroxymethylation in osteoarthritic chondrocytes. Arthritis Rheumatol 2015; 67(8): 2129-40. [http://dx.doi.org/10.1002/art.39179] [PMID: 25940674]

[67] El Mansouri FE, Nebbaki SS, Kapoor M, et al. Lysine-specific demethylase 1-mediated demethylation of histone H3 lysine 9 contributes to interleukin $1 \beta$-induced microsomal prostaglandin E synthase 1 expression in human osteoarthritic chondrocytes. Arthritis Res Ther 2014; 16(3): R113.

[http://dx.doi.org/10.1186/ar4564] [PMID: 24886859] 
[68] Morgan BA. Hox genes and embryonic development. Poult Sci 1997; 76(1): 96-104. [http://dx.doi.org/10.1093/ps/76.1.96] [PMID: 9037695]

[69] Xu Y, Barter MJ, Swan DC, et al. Identification of the pathogenic pathways in osteoarthritic hip cartilage: commonality and discord between hip and knee OA. Osteoarthritis Cartilage 2012; 20(9): 1029-38.

[http://dx.doi.org/10.1016/j.joca.2012.05.006] [PMID: 22659600]

[70] Imagawa K, de Andrés MC, Hashimoto K, et al. The epigenetic effect of glucosamine and a nuclear factor-kappa B (NF-kB) inhibitor on primary human chondrocytes--implications for osteoarthritis. Biochem Biophys Res Commun 2011; 405(3): 362-7. [http://dx.doi.org/10.1016/j.bbrc.2011.01.007] [PMID: 21219853]

\section{(C) 2018 Antonio Miranda-Duarte.}

This is an open access article distributed under the terms of the Creative Commons Attribution 4.0 International Public License (CC-BY 4.0), a copy of which is available at: (https:/creativecommons.org/licenses/by/4.0/legalcode). This license permits unrestricted use, distribution, and reproduction in any medium, provided the original author and source are credited. 